\title{
AUGMENTED REALITY (AR) IN PHYSICS LEARNING: OPPORTUNITIES TO IMPROVE TEACHER AND STUDENT INTERACTION IN ONLINE LEARNING
}

\author{
Siti Nurhasanah ${ }^{1 *}$, Abdurrahman ${ }^{2}$, Doni Andra ${ }^{3}$, Kartini Herlina ${ }^{4}$ \\ ${ }^{1,2,3,4}$ Department of Physics Education, Postgraduate Program, Universitas Lampung, Lampung, Indonesia
}

*Corresponding author: sitin7807@gmail.com

\begin{tabular}{l}
\hline \hline \multicolumn{1}{c}{ Article Info } \\
\hline Article History \\
Received: June, 2021 \\
Accepted: July 15, 2021 \\
Published: July 31, 2021 \\
\hline Keywords: \\
Augmented Reality (AR) \\
Teacher and student interaction \\
The covid-19 pandemic
\end{tabular}

\begin{abstract}
This study aims to describe the views of teachers and students in Islamic schools regarding Augmented Reality (AR) assisted learning to facilitate student involvement in learning, as well as increase teacher-student interactions in the learning process during the Covid-19 pandemic. This study uses a mixed method with a qualitative-quantitative explanatory design. The data collection technique used a questionnaire involving 31 respondents, 3 teachers, and 3 students as resource persons in three Islamic high schools in Lampung Province. The results of the study show that AR-assisted methods have the potential to increase teacher-student interaction by implementing a Learning Management System (LMS) that suits their needs and learning facilities. The results also show that AR provides an effective learning experience, because it displays 3D images so that it is easily accepted by students and makes students interested in learning during online learning. Therefore, the use of AR in learning has the opportunity to increase learning interactions between teachers and students.
\end{abstract}

\section{AUGMENTED REALITY (AR) DALAM PEMBELAJARAN FISIKA: PELUANG UNTUK MENINGKATKAN INTERAKSI GURU DAN SISWA DALAM PEMBELAJARAN ONLINE}

\section{Kata Kunci:}

Augmented Reality (AR) Interaksi guru dan siswa Pandemi covid-19

ABSTRAK
Penelitian ini bertujuan untuk mendeskripsikan pandangan Guru
dan Siswa di sekolah Islam tentang pembelajaran berbantuan
Augmented Reality (AR) untuk menfasilitasi keterlibatan siswa
dalam pembelajaran, serta meningkatkan interaksi Guru dengan
Siswa pada proses pembelajaran di masa Pandemi Covid-19 ini.
Penelitian ini menggunakan metode campuran dengan design
explanatory kualitatif-kuantitaif design. Teknik penggumpulan
data menggunakan angket yang melibatkan 31 responden, 3 Guru,
dan 3 Siswa sebagai narasumber di tiga Sekolah Menengah Atas
Islam di Provinsi Lampung. Hasil penelitian menunjukkan metode
berbantuan AR berpotensi meningkatkan interaksi Guru dan Siswa
dengan menerapkan Learning Management System (LMS) yang
sesuai kebutuhan dan fasilitas belajar. Hasil penelitian juga
menunjukkan bahwa AR memberikan pengalaman belajar yang
efektif, karena memunculkan gambar 3D sehingga mudah diterima
siswa dan membuat siswa tertarik untuk belajar selama
Pembelajaran daring. Oleh karenanya, pemanfaatan AR dalam
pembelajaran berpeluang untuk meningkatkan interaksi
pembelajaran antara Guru dengan Siswa.




\section{INTRODUCTION}

The 21 st century offers life in a world without boundaries, globalization, internationalization, and the rapid explosion of information and communication technology, so that the implications of these developments will result in the expansion of knowledge which in turn has a direct impact on the economic sector, cultural development, and political life of a country [1]. The very rapid development of technology in the era of the industrial revolution 4.0 has triggered developments in education in various countries, including changes in the education system in Indonesia. [2].

One of the most influential roles in education is the teacher. In responding to the era of globalization, teachers are required to adapt not only to transfer knowledge but also to shape character, morals, and emotions.[3]. Therefore, the Indonesian government seeks to reform the education curriculum that is oriented towards three educational concepts, Century Skills, Scientific Approach, and Authentic Assessment. [4].

Education is one vehicle to improve the quality of Human Resources. In education, the learning process is the main thing, because it involves the process of teaching and learning activities that provide interaction or reciprocal relationships between teachers and students in educational situations [3]. A learning program is said to be effective if it succeeds in making students achieve instructional goals, provides an attractive learning experience, involves students actively in supporting the achievement of instructional goals, and has facilities that support the teaching and learning process [5]. Educational goals will be achieved if teachers can encourage students to be actively involved in the learning process, in this context learning science (Physics) [6]. Active student involvement in the science learning process will affect students' ability to improve knowledge, skills, and character in scientific inquiry. In fact, many students have difficulty achieving good learning achievement, due to the lack of innovation in the delivery of knowledge in learning. Many students feel bored to learn, so the students' abilities cannot be developed optimally. Due to the lack of variety of learning methods applied in schools, students often feel bored and lazy to study [7].

Covid-19 or better known as "coronavirus" has changed human lifestyles in various sectors of life, including education. The implementation of learning that was originally offline has now turned into an online system for the safety of all parties. Since Covid-19 was declared a global pandemic and the National Disaster Management Agency declared a national emergency status, the learning process that was originally dominated by classical became non-classical or online [8]. Various efforts were made by schools to adapt to the new learning environment.

Climate change in education has resulted in changes in the learning system to become dependent on online technology. Classical education has turned into virtual education. Learning that was previously done in schools is now online and can be done from anywhere, all learning interactions are all digital. With the implementation of an onlinebased learning process, various impacts are obtained, including negative impacts. The involvement of students in the process of acquiring knowledge becomes very passive. Currently, educational technology has undergone many developments. Even now, Augmented reality (AR) technology is emerging which is used in the learning process to visualize science phenomena in $3 \mathrm{D}$ [9]. AR is a term to combine the real world and the virtual world created by computers, so the line between virtual and reality is very thin. This AR system is different from Virtual Reality (VR) which is a completely Virtual Environment [10][11]. 
$\mathrm{AR}$ is a $3 \mathrm{D}$ technology that can improve students' visuals to see the real world environment generated by computers through software using images from sensor perceptions by displaying contextual information, lately AR has also become popular in relation to educational research topics, because its devices are low cost with innovative features and create more efficient learning and better results. AR is very useful for learning Science, Technology, Engineering, and Mathematics (STEM), such as for practicing spatial abilities, practical skills, conceptual understanding and scientific inquiry learning [12]. AR provides new possibilities for simulating a teaching environment, experiencing the teaching process and promoting specific teaching interactions, including virtual-real blended, real-time interactive or three-dimensional immersion [13]. AR is one of the advanced technologies that emerge today and is widely used in various sectors such as medical surgery, medicine, and infrastructure design [14][15].

Learning innovations involving AR technology open new horizons for students, students are faced directly with phenomena in three-dimensional form so that learning is more fun and meaningful. The main advantage of using AR in learning is that it can direct a person to experience an artificially enhanced reality so that it represents real objects using technological devices such as smartphones, tablets, and computers through camera features [16]. AR use requires assistance from other devices, such as smartphones or with the android operating system [17]. Moreover, Android provides an open platform for developers to create their own applications that can be used by various mobile devices [18]. This technology uses abstract concepts that can be modified and presented in a more realistic model [19].

In the process of learning physics, students are required to be active and understand the concept well. Because physics concepts cannot be learned only by listening, taking notes, and remembering, but also through practicing observing, experimenting, discussing, paying attention, answering questions and applying concepts and communicating the results of a lesson [20]. Physics provides knowledge about nature and its phenomena, from the real to the abstract, so it takes imagination to study physics [21].

The phenomena discussed in physics are often familiar to everyday life. To help students understand physics well, an appropriate learning approach is needed. Previous research has provided ideas for delivering learning by utilizing Augmented Reality (AR) technology [22]. The use of AR in learning provides several benefits [23]. One of the benefits offered is that AR technology can stimulate several senses, such as: touch, sight, and hearing. Thus, students will be actively involved in the learning process. In contrast, in traditional teaching techniques students can only receive information one by one [24].

The use of AR can help students to learn in a more interesting way and allow students to get information visually and clearly with online methods. The impact of the Covid-19 pandemic has led to the implementation of various policies to break the chain of the spread of the virus. Education in Indonesia is also one aspect that must adapt. Based on the Letter of the Minister of Education and Culture No. 4 of 2020 concerning the Implementation of Policies and Education in the Corona Virus Disease (Covid 19) Emergency Period, the Ministry of Education replaces the offline teaching and learning process into learning using an online system [25]. Various distance learning media were tried and used. Facilities that can be used as online learning media include Schoology, Google Classroom, Google Form, WhatsApp groups, and other media [25]. Online learning is not just a process of transferring information through internet media or just giving assignments sent through applications, but online learning must be planned, implemented, and evaluated as well as classroom learning [26]. A recent meta-analysis of 
online learning found that online learning is more effective than classroom learning [27][28][29][30].

Physics is one of the subjects that is closely related to everyday life [20]. ARbased learning provides information that is presented "visually", learning Physics with this method has the opportunity to increase interaction between students and teachers in online learning. By learning with the AR method, it is expected that students are able to receive information well and can improve their ability to understand the information [31]. The development of an AR-based learning process can be a solution to increase interaction between teachers and students during the Covid-19 pandemic. This study aims to describe the opportunities for implementing Augmented Reality (AR)-based learning in improving teacher and student interactions during the Covid-19 Pandemic.

\section{METHOD}

This research is a mixed-methods study with a qualitative-quantitative explanatory design. The mixed methods sequential explanatory design consists of two different phases: quantitative followed by qualitative. In this design, the researcher first collects and analyzes quantitative (numeric) data by surveying 31 teachers in Islamic secondary schools in Lampung Province through the google form instrument. Qualitative data (text) was collected and analyzed from the results of interviews with 3 representatives of Physics Teachers and 3 Students from a school in Lampung Province to help explain or describe the quantitative results obtained in the first stage.

The second phase, qualitative, builds on the quantitative phase, and the two phases are linked to an intermediate phase in the study. The rationale for this approach is that quantitative data and subsequent analysis provide a general understanding of the research problem.

The research design schematically can be seen in Figure 1 as follows.

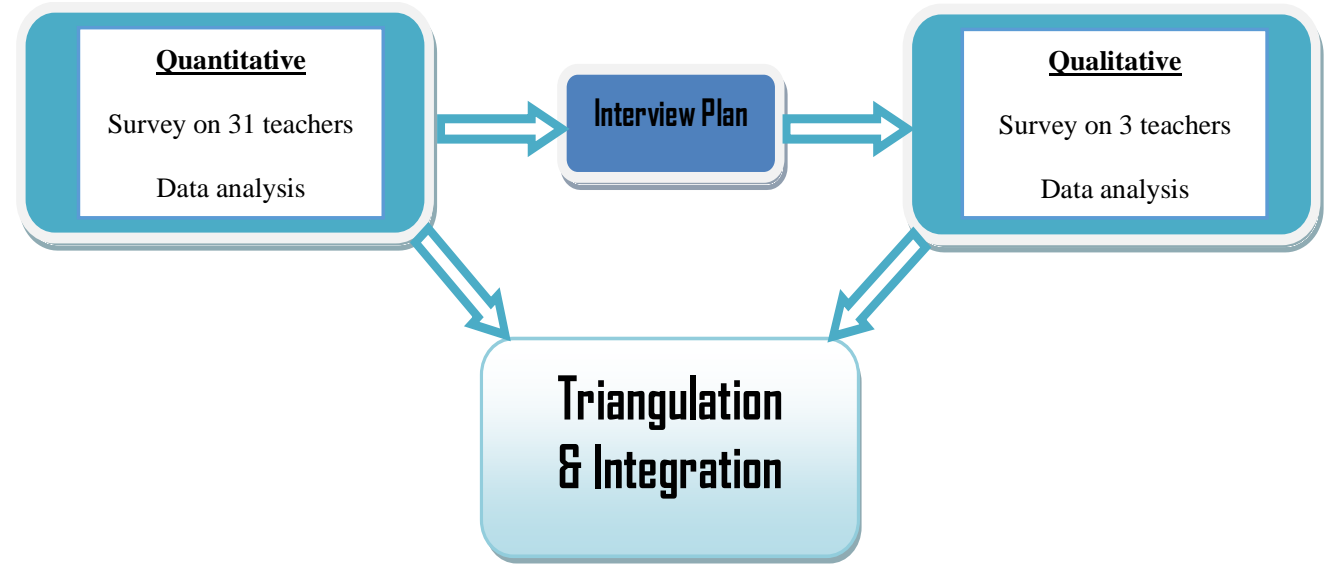

Figure 1. Research Design

Questionnaires given to teachers and students contain questions to see how the physics learning process is going during the COVID-19 pandemic. The questionnaire instrument used in the study consisted of questions using a Likert scale. The Likert scale is a scale used to measure attitudes, opinions, and perceptions of a person or group of people about a social phenomenon. The lowest scale used is 1 and the highest is 5 , as presented in Table 1. 
Table 1. Likert Scale in Questionnaire

\begin{tabular}{ccc}
\hline Scale & \multicolumn{2}{c}{ Categories on Each Aspect } \\
\cline { 2 - 3 } & Category & Aspect \\
\hline 1 & Strongly disagree & Sometimes \\
2 & Disagree & Seldom \\
3 & Agree & Often \\
4 & Strongly agree & Very often \\
\hline
\end{tabular}

The data from the questionnaire were then analyzed quantitatively and displayed in the form of a percentage (\%). The percentage value is calculated using the following formula:

With:

$$
\mathrm{P}=\frac{\mathrm{F}}{\mathrm{N}} \times 100 \%
$$

$\mathrm{P}=$ Percentage

$\mathrm{F}=$ Total score of respondents

$\mathrm{N}=$ Total maximum score.

The data of interactions between teachers and students during the COVID-19 pandemic, the percentage of the questionnaire results were interpreted into categories according to Table 2 .

Table 2. Interpretation of Student Perceptions About Learning during the COVID-19 Pandemic

\begin{tabular}{cc}
\hline Percentage (\%) & Category \\
\hline $0-19,99$ & Very poor \\
$20-39,99$ & Poor \\
$40-59,99$ & Average \\
$60-79,99$ & Good \\
$80-100$ & Very Good \\
\hline
\end{tabular}

\section{RESULTS AND DISCUSSION}

Based on the answers from the selected research subjects, it is known that according to the subjects, the learning process by involving Augmented Reality (AR) technology can help students understand abstract physics concepts, increase interaction between teachers and students, and facilitate science learning activities ( physics). This is confirmed by the results of previous research which confirms that Augmented Reality (AR) is a feature that can clearly describe how the global warming process occurs and can train students' scientific literacy in the form of images, videos, and others [32]. In this session, the views of teachers and students in Islamic schools will be described regarding the offline learning process, student involvement in learning, teacher-student interactions in the learning process during the Covid-19 pandemic, and the effect of Augmented Reality (AR) assisted learning in facilitating student engagement. in the learning process.

\subsection{Quantitative Analysis}

The following is a profile of online learning in the science subject "Physics" in several Islamic high schools in Lampung Province. 


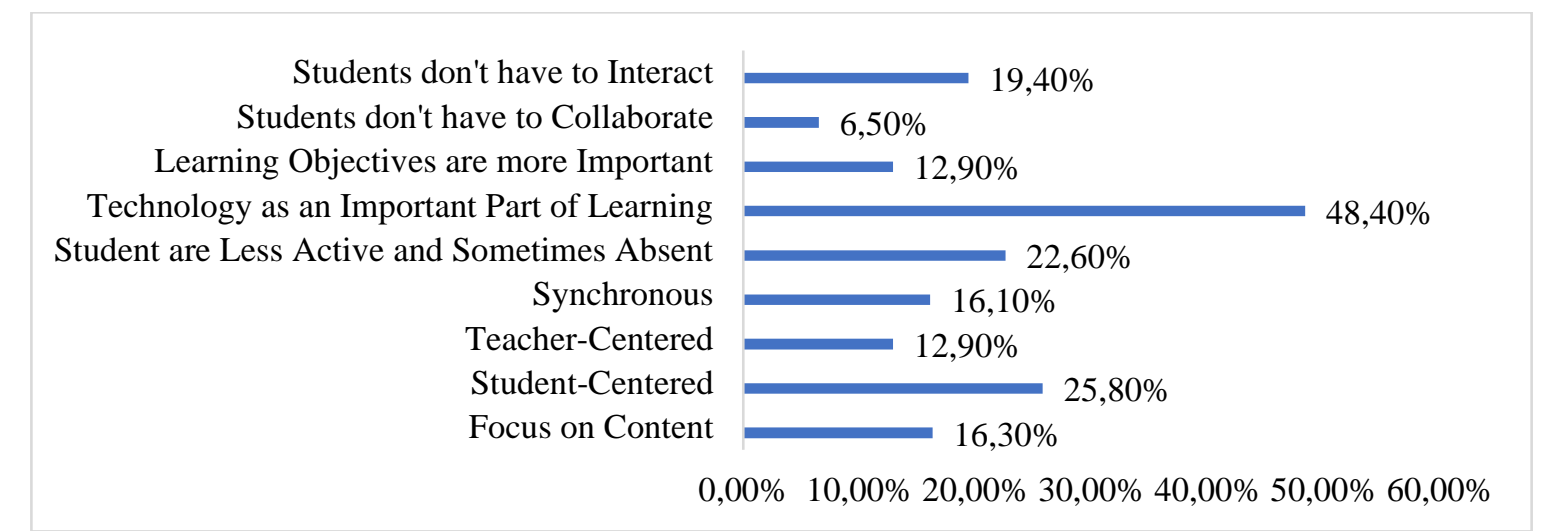

Figure 2. Profile of Online Learning During the Covid-19 Pandemic

From Figure 2 we can see that learning is more focused on content and technology is the most important part. Furthermore, the teacher considers that it is very important to provide information about the importance of student involvement in the online learning process during the Covid-19 pandemic so that students can be more focused in online learning. This information is shown in Figure 3 below.

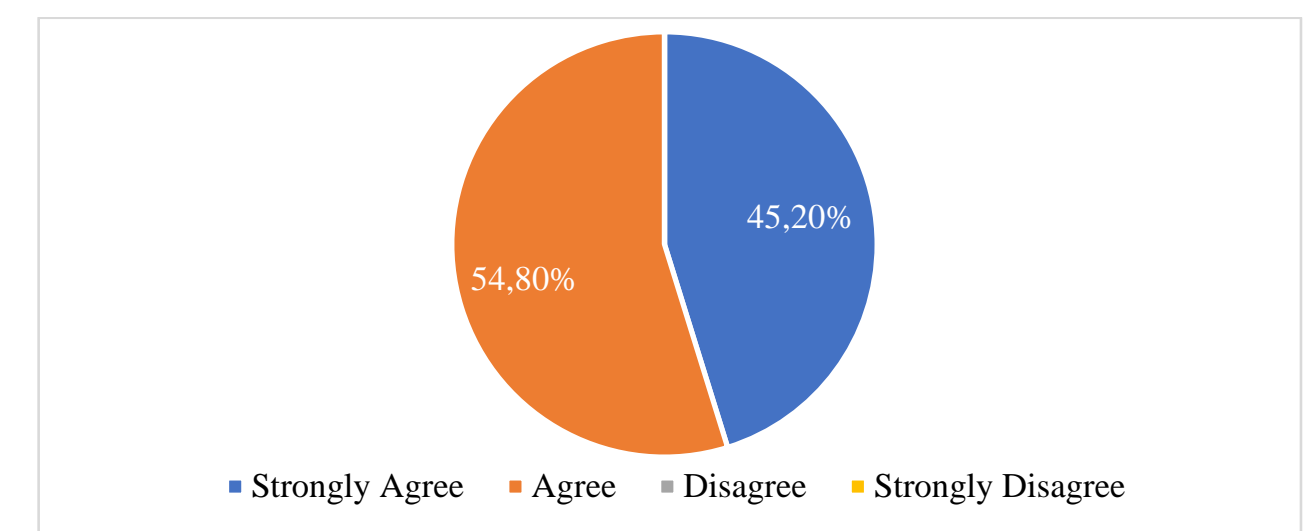

Figure 3. Teachers' Perspectives on The Importance of Directing Student Activities in Learning

From Figure 3 it can be seen that teachers consider it important to involve students in providing inside information about the learning process during the Covid-19 pandemic. In addition, to make the online learning process run effectively, the teacher assesses that it is necessary to prepare several learning methods that are not boring so that students are actively involved. This information is described by figure 4 .

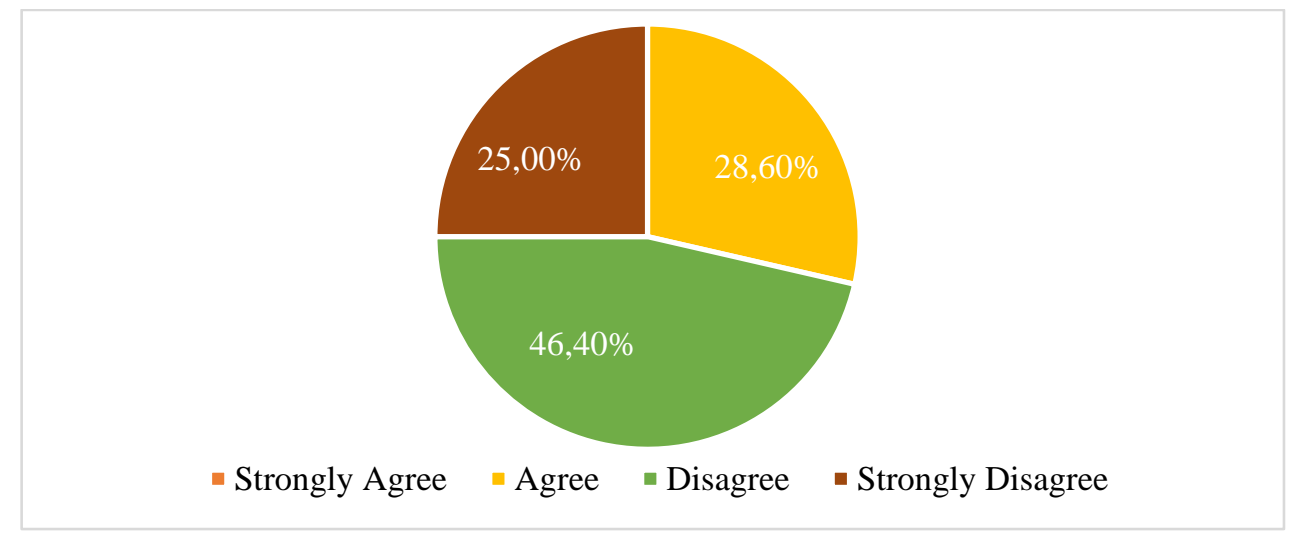

Figure 4. Teacher and Student Perspectives on Teachers Who are Less Tech-Savvy 
From Figure 4 it can be seen that in the online learning process, many teachers feel stressed because of the lack of ability and training to utilize technology in learning, so that some teachers are less able to adapt to this kind of learning situation.

In preparing learning materials independently, teachers can take material from the internet or other sources and then adjust it to the learning objectives, and choose an appropriate and easy-to-use Learning Management System (LMS) platform (Google Classroom, Ruang Guru, Edmodo, Schoology, Smart School, Moodle, etc.). Furthermore, so that students are actively involved in the learning process, the teacher believes that the media used must be diverse. Various interesting media platforms according to the teacher's perspective are shown in Figure 5.

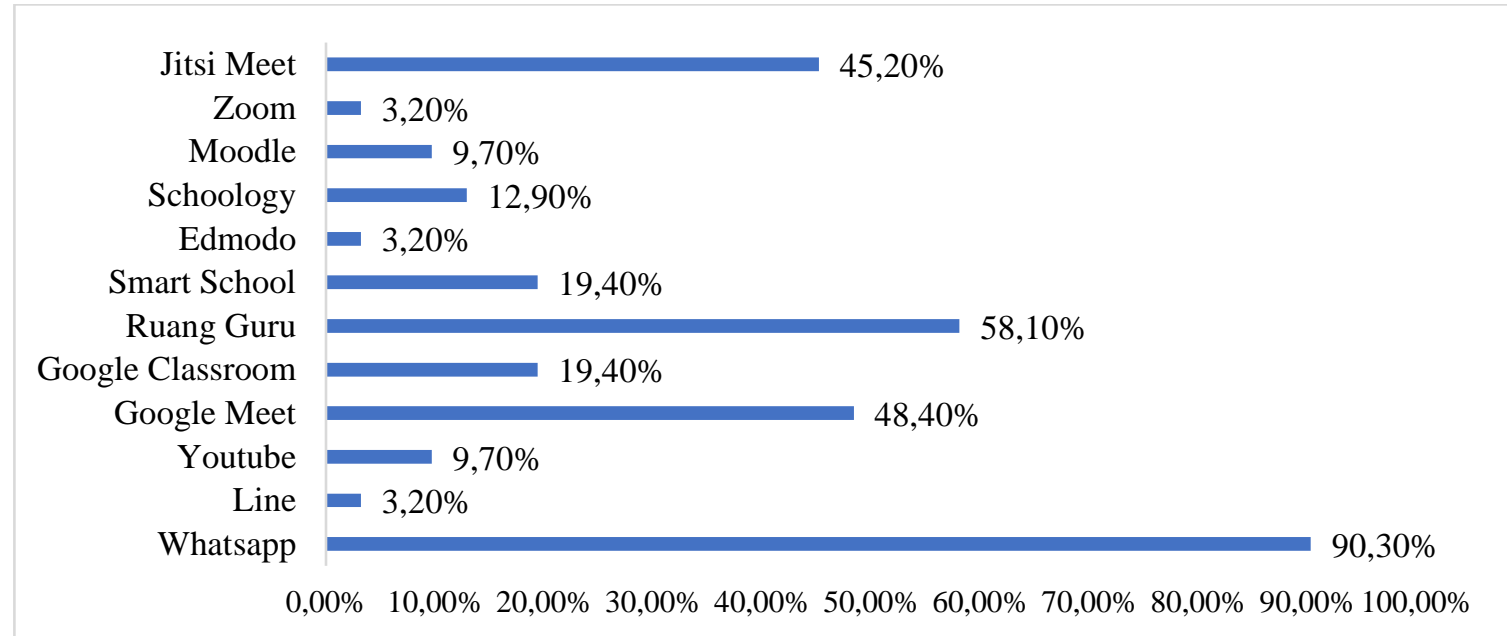

Figure 5. Various learning media platforms used by teachers

From Figure 5, it is known that the Learning Management System applications in the form of WhatsApp and Google Classroom are mostly used by physics teachers. This is because these platforms are often used and are considered easier to operate, but the limitations on these two platforms can be an obstacle to conveying information optimally and make it impossible for teachers and students to improve learning interactions.

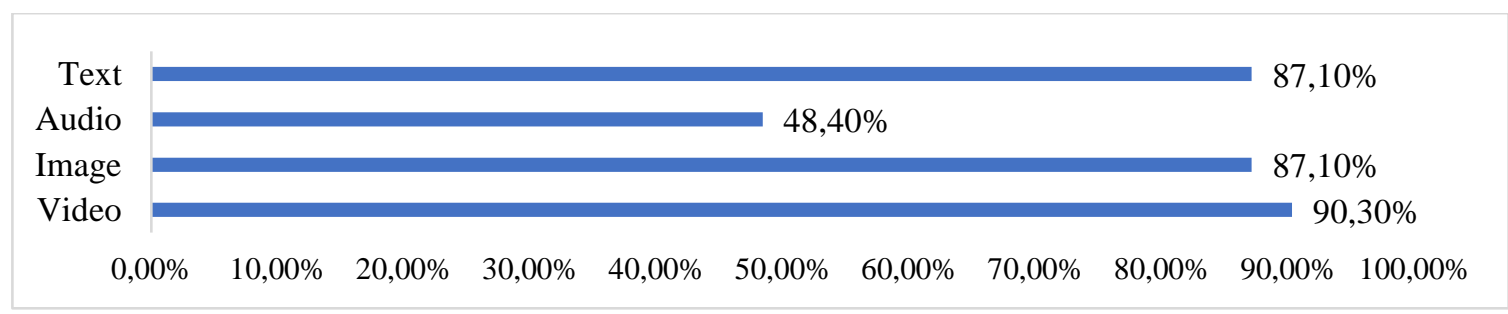

Figure 6. Various learning media used by teachers.

From Figure 6 it can be seen that several forms of media are needed in the form of video, image, audio, and text so that student involvement in the learning process can run effectively. In the Physics learning process, if you combine the four media aid elements and use technology equipped with 3D virtual animation, with moving images commonly called Augmented Reality (AR) it can help students understand Physics concepts and increase interaction between teachers and students. 


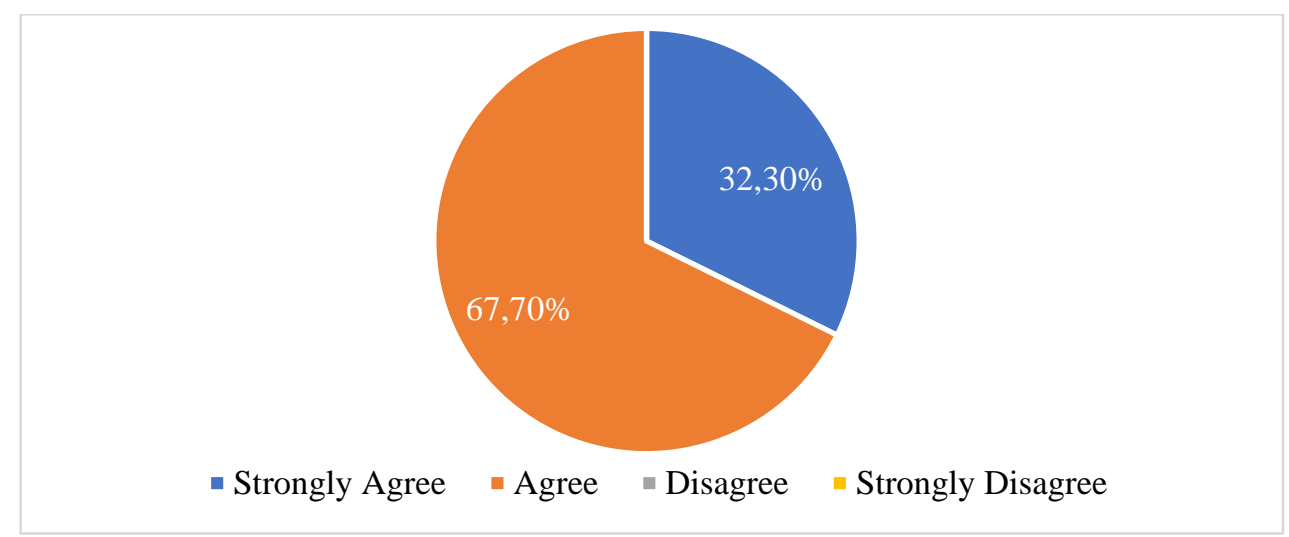

Figure 7. Augmented Reality-Assisted Physics Learning

From Figure 7 it is known that teachers and students strongly agree and believe that the Augmented Reality-assisted physics learning process can help students understand information more easily and improve teacher and student interactions in online learning. So it can be concluded that AR has the potential to be the main alternative in learning Physics in the New Normal era of the Covid-19 pandemic.

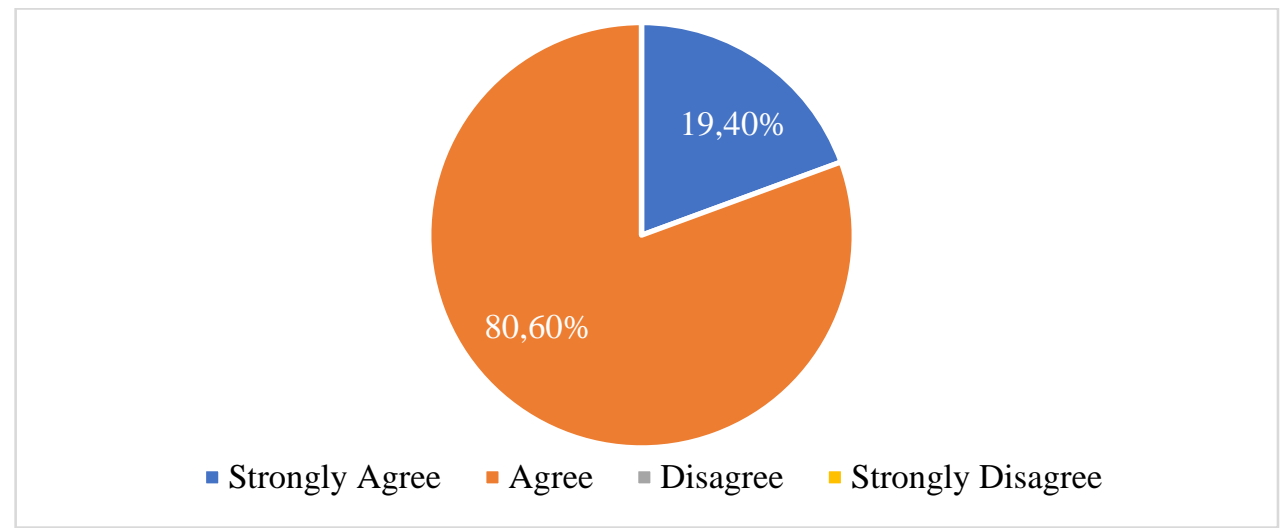

Figure 8. Augmented Reality is Believed to be The Main Learning Media in The New Normal Era of The Covid-19 Pandemic.

Figure 8 shows that Augmented Reality is believed to be the main alternative for physics learning media during the Covid-19 pandemic, some respondents think that the interaction between teachers and students can be more active and can also help students in independent learning.

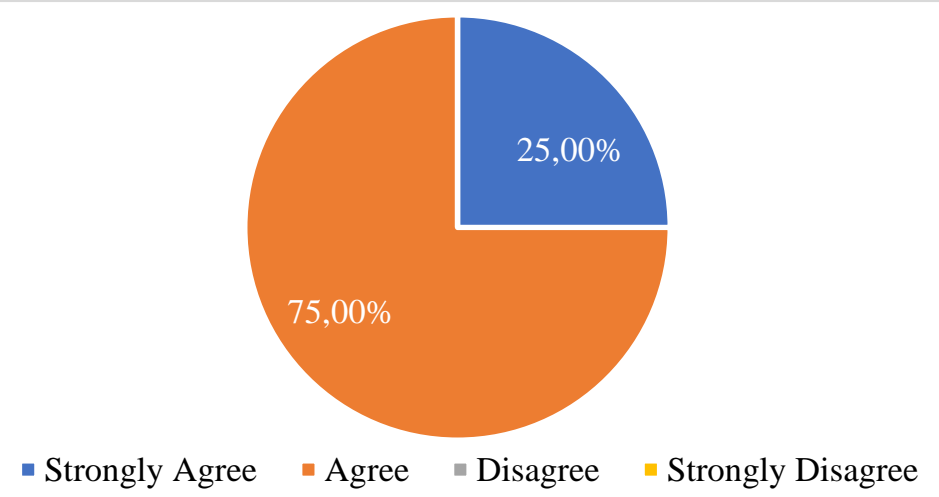

Figure 9. Augmented Reality is Believed to be The Main Alternative in Learning in the Covid-19 Era 
From Figure 9 it can be seen that teachers and students agree that learning physics equipped with Augmented Reality can attract students' interest in learning physics and activate teacher and student interactions in online learning. So that the possibility of students to absorb the lesson is higher.

\subsection{Qualitative Analysis}

Interviews were conducted with 3 Physics Teachers and 3 Students in Lampung Province to analyze the Augmented Reality-assisted learning method used during the physics learning process. The following are the codes for the teachers who were interviewed as resource persons by the researcher:

Table 3. Utilization of The Learning Management System Application

\begin{tabular}{ccl}
\hline No & School Code & \multicolumn{1}{c}{ Question } \\
\hline 1 & School 1 & $\begin{array}{l}\text { What Learning Management System } \\
\text { applications are used in school? }\end{array}$ \\
2 & School 2 & Why? \\
3 & School 3 & \\
\hline
\end{tabular}

According to Table 3, there are various versions of answers from each teacher as resource person, namely: School 1 stated that the Learning Management System application used was in the form of WhatsApp and Google Classroom, because the application was more effective, cheaper, and accessible even though there was minimal internet network. This is influenced by several factors, one of which is the geographical location of the school. Because the school is located in villages, the internet network is still difficult and students lack knowledge. In School 2, the school already has a website. However, the learning management system application used is WhatsApp and zoom as a medium of communication between students and teachers.

School 3 stated that learning activities at school were carried out face-to-face (offline) while still adhering to health protocols. This is because the condition of the school is an Islamic boarding school, so students who study are students at the Islamic boarding school, and are not allowed to bring or use cellphones and any gadgets while at school.

Table 4. Utilization of Augmented Reality

\begin{tabular}{ccl}
\hline No & School Code & \multicolumn{1}{c}{ Question } \\
\hline 1 & School 1 & Have you ever heard or know about \\
2 & School 2 & Augmented Reality? \\
3 & School 3 & \\
\hline
\end{tabular}

According to Table 4, for these questions, the respondents did not know or know Augmented Reality, even all the informants had never heard of the term Augmented Reality (AR), even the respondents as teachers had never used Augmented Reality in learning.

Table 5. Introduction to Augmented Reality by Students

\begin{tabular}{ccl}
\hline No & School Code & \multicolumn{1}{c}{ Question } \\
\hline 1 & School 1 & Have you ever heard or know \\
2 & School 2 & about Augmented Reality? \\
3 & School 3 & \\
\hline
\end{tabular}

According to Table 5, students are not familiar with Augmented Reality, in fact all respondents have never heard of the term Augmented Reality, and respondents as students have never used Augmented Reality media in learning. 
Table 6. Analysis of the Use of Augmented Reality (AR) from the Teacher's Perspective to Improve Teacher and Student Interactions

\begin{tabular}{ccl}
\hline No. & School Code & \multicolumn{1}{c}{ Question } \\
\hline 1 & School 1 & Do you think you need learning \\
2 & School 2 & methods with Augmented Reality \\
3 & School 3 & $\begin{array}{l}\text { (AR) to improve teacher-student } \\
\text { interactions? }\end{array}$ \\
\hline
\end{tabular}

According to Table 6, the majority of teachers agree that Augmented Reality can be used easily, but teachers need an explanation on how to use AR to improve the interaction between teachers and students. With the current state of the Covid-19 pandemic, the use of AR-based learning methods is very good because it can help teachers explain concepts, and students will be interested in understanding abstract physics concepts through learning with $3 \mathrm{D}$ views.

Table 7. Analysis of Student Interest in Learning with the Augmented Reality Method to Improve Science Skills

\begin{tabular}{ccc}
\hline No. & School Code & Question \\
\hline 1 & School 1 & Have you ever heard of or know \\
2 & School 2 & about Augmented Reality (AR)? \\
3 & School 3 & \\
\hline
\end{tabular}

According to Table 7, the majority of students are interested in learning by using Augmented Reality. The students found learning using AR more interesting than just listening to the teacher's explanation. The use of AR-based learning methods is very good because incorporating technology in learning can help students to accept the information presented and can make students interested in learning because learning is not boring.

Table 8. Analysis of the Benefits of Augmented Reality (AR) to Improve Teacher and Student Interactions based on Student Perspectives

\begin{tabular}{cll}
\hline No. & School Code & \multicolumn{1}{c}{ Question } \\
\hline 1 & School 1 & Are you interested in using Augmented \\
2 & School 2 & Reality in learning Physics to improve \\
3 & School 3 & Science skills? \\
\hline
\end{tabular}

According to Table 8, the majority of students agree that Augmented Reality can be used easily, but they suggest that they should be given instructions for use because it is a bit unfamiliar. Students also think that the use of AR in learning can increase the interaction between teachers and students. In the current Covid-19 pandemic, the use of AR-based learning methods is very interesting because it can attract students to study individually. With new technology-based methods, it can increase interaction with teachers.

\section{CONCLUSION}

In the process of learning physics, teachers have not been able to maximize the process of delivering information to students. The media used have not fully used interactive media, therefore it is necessary to develop a learning process that considers technological developments, one of which is by utilizing Augmented Reality (AR). The use of AR in learning can help students understand abstract physics concepts and increase interaction between teachers and students and facilitate learning activities. The learning methods expected by respondents in this study are (1) The learning delivered by the teacher can be accepted by students in accordance with the core learning competencies, basic competencies, indicators, and learning objectives, (2) Utilizing AR which includes video, 
audio, moving animation 3D, work steps, and material summaries, (3) Easy to use and helps in understanding learning, (4) Helps improve interaction between teachers and students in the online learning process. Based on the results of this study, teachers must be able to improve the quality in the learning process, one of which is by applying AR-based learning methods that can facilitate the teaching and learning process, so that students can compete globally and can keep up with the times.

\section{REFERENCES}

[1] P. Turiman, J. Omar, A. M. Daud, and K. Osman, "Fostering the 21 st Century Skills through Scientific Literacy and Science Process Skills," Procedia - Soc. Behav. Sci., vol. 59, pp. 110-116, 2012, doi: 10.1016/j.sbspro.2012.09.253.

[2] D. Lase, "Pendidikan di Era Revolusi Industri 4.0," Res. Gate, vol. 3, no. 1, 2019, doi: 10.13140/RG.2.2.30831.59043.

[3] F. Nastiti and A. Abdu, "Kajian: Kesiapan Pendidikan Indonesia Menghadapi Era Society 5.0," Edcomtech J. Kaji. Teknol. Pendidik., vol. 5, no. 1, pp. 61-66, 2020, doi: 10.17977/um039v5i12020p061.

[4] I. G. A. Wisnu Wibowo, "Peningkatan Keterampilan Ilmiah Peserta Didik dalam Pembelajaran Fisika Melalui Penerapan Pendekatan STEM dan E-Learning," $J$. Educ. Action Res., vol. 2, no. 4, p. 315, 2018, doi: 10.23887/jear.v2i4.16321.

[5] A. Rohmawati, "Efektivitas Pembelajaran Afifatu," J. Pendidik. Usia Dini, vol. 9, no. 1, pp. 15-32, 2015, [Online]. Available: e-mail: paud.ppsunj@gmail.com\%0AAbstract:

[6] T. Mayasari, A. Kadarohman, D. Rusdiana, and I. Kaniawati, "Apakah Model Pembelajaran Problem Based Learning Dan Project Based Learning Mampu Melatihkan Keterampilan Abad 21?," J. Pendidik. Fis. dan Keilmuan, vol. 2, no. 1, p. 48, 2016, doi: 10.25273/jpfk.v2i1.24.

[7] S. Sutrisno and M. S. Zuhri, "PKM Peningkatan Kompetensi Guru Melalui Pelatihan Penulisan Artikel Ilmiah Penelitian Tindakan Kelas," J. Dedicators Community, vol. 3, no. 1, pp. 53-61, 2019, doi: 10.34001/jdc.v3i1.793.

[8] L. Handayani, "Keuntungan , Kendala dan Solusi Pembelajaran Online Selama Pandemi Covid-19 : Studi Ekploratif di SMPN 3 Bae Kudus Lina Handayani," J. Ind. Eng. Manag. Res., vol. 1, no. 2, pp. 15-23, 2020.

[9] F. Z. Adami and C. Budihartanti, "Penerapan Teknologi Augmented Reality Pada Media Pembelajaran Sistem Pencernaan Berbasis Android," Tek. Komput. AMIK BSI, vol. 2, no. 1, pp. 122-131, 2016, [Online]. Available: http://ejournal.bsi.ac.id/ejurnal/index.php/jtk/article/viewFile/370/279.

[10] Ronald T. Azuma, "A survey of augmented reality," FTeleoperators Virtual Environ., vol. 6, no. 4, pp. 355-385, 1997, doi: 10.1561/1100000049.

[11] K. Lee, "Augmented Reality in Education and Training," TechTrends, vol. 56, no. 2, pp. 13-21, 2012, doi: 10.1007/s11528-012-0559-3.

[12] I. C. Technology, “唐跃桓 1 杨其静 1 李秋芸 2 朱博鸿 3,” vol. 1, no. 2, pp. 7594, 2020.

[13] S. Cai, F. K. Chiang, and X. Wang, "Using the augmented reality 3D technique for a convex imaging experiment in a physics course," Int. J. Eng. Educ., vol. 29, no. 4, pp. 856-865, 2013.

[14] C. Kamphuis, E. Barsom, M. Schijven, and N. Christoph, "Augmented reality in medical education?," Perspect. Med. Educ., vol. 3, no. 4, pp. 300-311, 2014, doi: 10.1007/s40037-013-0107-7.

[15] W. Höhl and D. Broschart, "Augmented reality in architecture and urban planning," 
gis.Science - Die Zeitschrift fur Geoinformatik, vol. 1, pp. 111-118, 2015.

[16] I. Sural, "Mobile augmented reality applications in education," Mob. Technol. Augment. Real. Open Educ., no. 2009, pp. 200-214, 2017, doi: 10.4018/978-15225-2110-5.ch010.

[17] A. K. Wahyudi, "ARca: Pengembangan Buku Interaktif Berbasis Augmented Reality dengan Smartphone Android," 96 Jnteti, vol. 3, no. 2, pp. 96-102, 2014, doi: 10.22146/jnteti.v3i2.60.

[18] D. Ambarwulan and D. Muliyati, "The Design of Augmented Reality Application as Learning Media Marker-Based for Android Smartphone," J. Penelit. Pengemb. Pendidik. Fis., vol. 2, no. 1, pp. 73-80, 2016.

[19] M. Nazar et al., "Development of Augmented Reality application for learning the concept of molecular geometry," J. Phys. Conf. Ser., vol. 1460, no. 1, 2020, doi: 10.1088/1742-6596/1460/1/012083.

[20] S. Chodijah, A. Fauzi, and R. Wulan, "Pengembangan Perangkat Pembelajaran Fisika Menggunakan Model Guided Inquiryyang Dilengkapi Penilaian Portofolio Pada Materi Gerak Melingkar," J. Penelit. Pembelajaran Fis., vol. 1, pp. 1-19, 2012, [Online]. Available: http://ejournal.unp.ac.id.

[21] dan I. Y. rizky Amalia, "Seminar Nasional Pendidikan Fisika 2018 Seminar Nasional Pendidikan Fisika 2019," Penerapan Pendekatan Probl. Posing untuk Meningkat. Kemamp. Represent. Vis. Mat. Siswa SMP, vol. 3, no. 2, pp. 227-234, 2018.

[22] D. Sumardani, A. Putri, R. R. Saraswati, D. Muliyati, and F. Bakri, "Virtual Reality Media: The Simulation of Relativity Theory on Smartphone," Form. J. Ilm. Pendidik. MIPA, vol. 10, no. 1, pp. 13-24, 2020, doi: 10.30998/formatif.v10i1.5063.

[23] K. R. Parvathy, M. L. Mclain, K. Bijlani, R. Jayakrishnan, and R. R. Bhavani, "Emerging Research in Computing, Information, Communication and Applications," Emerg. Res. Comput. Information, Commun. Appl., pp. 69-78, 2016, doi: 10.1007/978-81-322-2553-9.

[24] H. Kaufmann, "Collaborative Augmented Reality in Education," Lect. Notes Networks Syst., vol. 80, no. March 2003, pp. 719-732, 2012, doi: 10.1007/978-3030-23162-0_65.

[25] A. Rachmat and I. Krisnadi, "Analisis Efektifitas Pembelajaran Daring (Online) Untuk Siswa SMK Negeri 8 Kota Tangerang Pada Saat Pandemi Covid 19," J. Pendidik., vol. 1, no. 1, pp. 1-7, 2020.

[26] A. S. Syarifudin, "Impelementasi Pembelajaran Daring Untuk Meningkatkan Mutu Pendidikan Sebagai Dampak Diterapkannya Social Distancing," J. Pendidik. Bhs. dan Sastra Indones. Met., vol. 5, no. 1, pp. 31-34, 2020, doi: 10.21107/metalingua.v5i1.7072.

[27] R. M. Bernard, E. Borokhovski, R. F. Schmid, R. M. Tamim, and P. C. Abrami, "A meta-analysis of blended learning and technology use in higher education: From the general to the applied," J. Comput. High. Educ., vol. 26, no. 1, pp. 87-122, 2014, doi: 10.1007/s12528-013-9077-3.

[28] B. Means, Y. Toyama, R. Murphy, and M. Baki, "The effectiveness of online and blended learning: A meta-analysis of the empirical literature," Teach. Coll. Rec., vol. 115, no. 3, 2013.

[29] H. M. Vo, C. Zhu, and N. A. Diep, "The effect of blended learning on student performance at course-level in higher education: A meta-analysis," Stud. Educ. Eval., vol. 53, pp. 17-28, 2017, doi: 10.1016/j.stueduc.2017.01.002.

[30] W. Winarno, "Design and Implementation of Web-Based Lecture Evaluation 
System," J. Pendidik. Islam, vol. 3, no. 2, p. 235, 2018, doi: 10.15575/jpi.v3i2.1583.

[31] I. A. Puspita and S. Wahyuni, "Pengembangan Lks ( Lembar Kerja Siswa ) Fisika Berbasis Ctl ( Contextual Teaching and Learning ) Untuk," no. 2013, pp. 376-383, 2014.

[32] A. Kholiq, "Development of B D F-AR 2 (Physics Digital Book Based Augmented Reality) to train students' scientific literacy on Global Warming Material," Berk. Ilm. Pendidik. Fis., vol. 8, no. 1, p. 50, 2020, doi: 10.20527/bipf.v8i1.7881. 